\title{
Mathematical Models to Predict Staphylococcus aureus Growth on Processed Cheeses
}

\author{
Kyungmi Kim, Heeyoung Lee, Jinsan Moon', Youngjo Kim², \\ Eunjeong $\mathrm{HeO}^{3}$, Hyunjung Park${ }^{4}$, and Yohan Yoon* \\ Department of Food and Nutrition, Sookmyung Women's University, Seoul 140-742, Korea \\ ${ }^{1}$ Veterinary Pharmaceutical Management Division, Animal, Plant and Fisheries Quarantine and Inspection Agency, \\ Anyang 430-824, Korea \\ ${ }^{2}$ Livestock Products Sanitation Division, Ministry of Food and Drug Safety, Osong 363-700, Korea \\ ${ }^{3}$ Food Microbiology Division, Ministry of Food and Drug Safety, Osong 363-700, Korea \\ ${ }^{4}$ Agro-Livestock and Fishery Products Policy Division, Ministry of Food and Drug Safety, Osong 363-700, Korea
}

(Received June 20, 2013/Revised July 24, 2013/Accepted August 14, 2013)

\begin{abstract}
This study developed predictive models for the kinetic behavior of Staphylococcus aureus on processed cheeses. Mozzarella slice cheese and cheddar slice cheese were inoculated with $0.1 \mathrm{ml}$ of a $S$. aureus strain mixture (ATCC13565, ATCC14458, ATCC23235, ATCC27664, and NCCP10826). The inoculated samples were then stored at $4^{\circ} \mathrm{C}(1440 \mathrm{~h}), 15^{\circ} \mathrm{C}(288 \mathrm{~h}), 25^{\circ} \mathrm{C}(72 \mathrm{~h})$, and $30^{\circ} \mathrm{C}(48 \mathrm{~h})$, and the growth of all bacteria and of $S$. aureus were enumerated on tryptic soy agar and mannitol salt agar, respectively. The Baranyi model was fitted to the growth data of $S$. aureus to calculate growth rate $\left(\mu_{\max } ; \log \mathrm{CFU} \cdot \mathrm{g}^{-1} \cdot \mathrm{h}^{-1}\right)$, lag phase duration (LPD; $\left.\mathrm{h}\right)$, lower asymptote (log CFU/ $\mathrm{g})$, and upper asymptote $(\log \mathrm{CFU} / \mathrm{g})$. The growth parameters were further analyzed using the square root model as a function of temperature. The model performance was validated with observed data, and the root mean square error (RMSE) was calculated. At $4^{\circ} \mathrm{C}, S$. aureus cell growth was not observed on either processed cheese, but $S$. aureus growth on the mozzarella and cheddar cheeses was observed at $15^{\circ} \mathrm{C}, 25^{\circ} \mathrm{C}$, and $30^{\circ} \mathrm{C}$. The $\mu_{\max }$ values increased, but LPD values decreased as storage temperature increased. In addition, the developed models showed acceptable performance $(\mathrm{RMSE}=0.3500-0.5344)$. This result indicates that the developed kinetic model should be useful in describing the growth pattern of $S$. aureus in processed cheeses.
\end{abstract}

Key words: Staphylococcus aureus, processed cheese, predictive model

\section{Introduction}

The consumption of cheese has increased globally, and in particular, in Korea, since the $1990 \mathrm{~s}^{1}$. Cheese is regarded as one of the safest foods, but it is often implicated in food-borne outbreaks, especially of Listeria monocytogenes, Staphylococcus aureus, and Escherichia coli ${ }^{2,3)}$. In general, there are many outbreaks of $S$. aureus ${ }^{4)}$. The bacterium produces enterotoxins, causing intoxication and food-borne illness ${ }^{5)}$. $S$. aureus usually exists on the skin and nasal passages, and the pathogen can easily contaminate food ${ }^{6,7)}$. The foods commonly associated with staphylococcal intoxication are meat products, salads, cream-filled bakery products, and dairy products $^{8)}$. To describe kinetic behavior of $S$. aureus in the

\footnotetext{
*Correspondence to: Yohan Yoon, Department of Food and Nutrition, Sookmyung Women's University, Seoul 140-742, Korea Tel: 82-2-2077-7585, Fax: 82-2-710-9479

E-mail: yyoon@sookmyung.ac.kr
}

foods, many mathematical models have been thus developed. However, there have been reports from many countries about $S$. aureus being isolated from various cheese products ${ }^{9,10)}$. Hence, many countries have a quantitative standard or "zero tolerance" policy to control the pathogens growing on cheese $^{11,12,13,14,15)}$. Furthermore, mathematical models need to be developed to describe kinetic behavior of $S$. aureus in cheese, which should be useful in exposure assessment.

Predictive microbiology has been used to develop mathematical models to predict the response of food-borne pathogens to food-related environments ${ }^{16,17)}$. Usually, mathematical models have been used for exposure assessment in microbial risk assessment ${ }^{18)}$. A primary model describes the kinetic behavior of food-borne pathogens on foods, and a secondary model describes environmental influences on kinetic parameters such as maximum specific growth rate $\left(\mu_{\max }\right)$ and lag phase duration (LPD) ${ }^{19)}$. Therefore, the objective of this study was to develop mathematical models to describe the kinetic behavior of $S$. aureus on cheese. 


\section{Materials and Methods}

\section{Inoculum preparation}

Colonies of $S$. aureus strains ATCC13565, ATCC14458, ATCC23235, ATCC27664, and NCCP10826 cultured on mannitol salt agar (MSA; $\mathrm{BBL}^{\mathrm{TM}}$, Becton Dickinson and Company, Sparks, MD, USA) were inoculated into $10 \mathrm{ml}$ tryptic soy broth $\left(\mathrm{TSB}\right.$; Bacto ${ }^{\mathrm{TM}}$, Becton Dickinson and Company, Sparks, MD, USA), and incubated at $35^{\circ} \mathrm{C}$ for $2 \mathrm{~h}$. An aliquot $(0.1 \mathrm{ml})$ of each culture suspension was inoculated into $10 \mathrm{ml} \mathrm{TSB}$ for subculturing at $35^{\circ} \mathrm{C}$ for $24 \mathrm{~h}$. The cultures were then mixed and centrifuged at $1,912 \times g$ and $4^{\circ} \mathrm{C}$ for $15 \mathrm{~min}$. The resulting pellet was thoroughly washed with phosphate-buffered saline (PBS; $\mathrm{pH} 7.4, \mathrm{KH}_{2} \mathrm{PO}_{4} 0.2 \mathrm{~g}$, $\mathrm{Na}_{2} \mathrm{HPO}_{4} 1.5 \mathrm{~g}, \mathrm{NaCl} 8.0 \mathrm{~g}, \mathrm{KCl} 0.2 \mathrm{~g}$ per liter of distilled water) twice. The pellet was resuspended in PBS, and the cell suspension was then diluted with PBS to 5-6 log CFU/ml.

\section{Sample preparation and inoculation}

Two commercial processed cheeses (mozzarella and cheddar slice cheese) were used in this study. Each 18-gram formed slice of cheese was removed from its plastic wrapping and inoculated by spreading $0.1 \mathrm{ml}$ of the inoculum on its surface by using a sterile bent spreader. The samples were then returned to their original plastic wrapping, and two samples were sealed in a plastic bag by a sealer (Food Guard ${ }^{\circledR}$; Rollpack, Pyeongtaek, Gyeonggi-do, Korea). The sealed samples were then stored at $4^{\circ} \mathrm{C}, 15^{\circ} \mathrm{C}, 25^{\circ} \mathrm{C}$, and $30^{\circ} \mathrm{C}$ for $1440 \mathrm{~h}, 288 \mathrm{~h}, 72 \mathrm{~h}$, and $48 \mathrm{~h}$, respectively.

\section{Analyses}

To enumerate bacterial populations, the cheese samples were transferred to a filter bag (BagFilter ${ }^{\mathbb{R}}$, Interscience, St. Nom, France) containing $30 \mathrm{ml} 0.1 \%$ buffered peptone water (BPW; Difco ${ }^{\mathrm{TM}}$, Becton Dickinson and Company, Sparks, MD, USA). The bagged samples were homogenized in a pummeler (BagMixer ${ }^{\circledR}$, Interscience, St. Nom, France) for 2 $\mathrm{min}$, and the homogenates were then serially diluted with BPW. Aliquots $(0.1 \mathrm{ml})$ of the diluted homogenates were surface-plated onto tryptic soy agar (Difco ${ }^{\mathrm{TM}}$ ) and MSA for determining total bacterial counts and $S$. aureus counts, respectively. The plates were incubated at $35^{\circ} \mathrm{C}$ for $24 \mathrm{~h}$, and the colonies were manually counted. The $\mathrm{pH}$ of the homogenates was measured with a digital $\mathrm{pH}$ meter (Accument ${ }^{\circledR}$, Denver Instruments, Arvada, CO, USA). The water activity $\left(\mathrm{a}_{\mathrm{w}}\right)$ of the samples was measured with a water activity meter (Aquaspector $^{\circledR}$, NAGY Messsysteme GmbH, Germany).

\section{Primary model}

The procedure was performed twice with two replicates of each sample $(n=4)$. The Baranyi model ${ }^{20)}$ was fitted to the
$S$. aureus growth data for each cheese product and the kinetic parameters such as the maximum specific growth rate $\left(\mu_{\max }\right.$; $\log \mathrm{CFU} \cdot \mathrm{g}^{-1} \cdot \mathrm{h}^{-1}$ ) and LPD (h) were calculated with the DMFit package (Institute of Food Research, Norwich, UK).

\section{Secondary model}

The square root model was fitted to $\mu_{\max }$ and LPD values as a function of temperature to evaluate the effect of storage temperature on the kinetic parameters. The square root model and exponential decay model was suitable for fitting of $\mu_{\max }$ and LPD, respectively. The function of these models are as follows

$$
\sqrt{\mu_{\max }}=\alpha\left(T-T_{\min }\right)
$$

Where $\alpha$ is the slopes of linear regression, $T$ is storage temperature, and $T_{\min }$ is the theoretical minimum temperature value for the growth of $S$. aureus on processed cheese.

$\mathrm{LPD}=a \times e^{-b \times T}$

Where $a$ is the initial value, and $\mathrm{b}$ is the increase rate.

\section{Validation}

To validate the developed models, observed $S$. aureus cell counts were obtained from another study. These observed data were then compared with the predicted $S$. aureus cell counts, which were calculated using the models developed. Subsequently, the root mean square error (RMSE) was calculated to evaluate the model performance, as follows:

$$
\text { RMSE }=\sqrt{\frac{\sum(\text { observed values }- \text { predicted values })^{2}}{n-1}}
$$

In the above equation, " $n$ " represents the number of observations.

\section{Statistical analysis}

Growth parameters were analyzed by the general linear model procedure of $\mathrm{SAS}^{\circledR}$ version 9.2 (SAS Institute Inc., Cary, NC, USA), and the LS means among temperatures were compared with pairwise $t$-test at alpha $=0.05$.

\section{Results and Discussion}

No bacterial growth was observed at $4^{\circ} \mathrm{C}$ from samples from the mozzarella or the cheddar slice cheese (data not shown). Thus, primary models were developed using only the $S$. aureus growth data from the $15^{\circ} \mathrm{C}, 25^{\circ} \mathrm{C}$, and $30^{\circ} \mathrm{C}$. No growth at $4^{\circ} \mathrm{C}$ may be caused by lowered affinity for substrates because low temperature may decrese the active transport system ${ }^{21)}$. For both cheeses, the LPD values of $S$. 
aureus decreased from 3.10 to $48.00 \mathrm{~h}$ (mozzarella slice cheese) and from 0.08 to $130.01 \mathrm{~h}$ (cheddar slice cheese) as the storage temperature increased (Table 1). At $15^{\circ} \mathrm{C}$, LPD for the cheddar slice cheese $(130.01 \mathrm{~h})$ was longer $(P<0.05)$ than that of the mozzarella slice cheese ( $48 \mathrm{~h}$ ) (Table 1).

$S$. aureus cell counts from the mozzarella slice cheese gradually increased to $8.4 \log \mathrm{CFU} / \mathrm{g}$ at $15^{\circ} \mathrm{C}$. However, $S$. aureus cell counts on the cheddar cheese increased only to 4.9 $\log \mathrm{CFU} / \mathrm{g}$ at this temperature (Table 1). At 25 and $30^{\circ} \mathrm{C}, \mathrm{S}$. aureus growth was more obvious than at $15^{\circ} \mathrm{C}$. The $\mu_{\max }$ values (0.11-0.18 $\left.\log \mathrm{CFU} \cdot \mathrm{g}^{-1} \cdot \mathrm{h}^{-1}\right)$ were similar for mozzarella and cheddar cheese at $25^{\circ} \mathrm{C}$, but mozzarella cheese had significantly higher $(P<0.05) \mu_{\max }\left(0.52 \log \mathrm{CFU} \cdot \mathrm{g}^{-1} \cdot \mathrm{h}^{-1}\right)$ than cheddar cheese $\left(0.16 \log \mathrm{CFU} \cdot \mathrm{g}^{-1} \cdot \mathrm{h}^{-1}\right)$ at $30^{\circ} \mathrm{C}$ (Table 1$)$. To investigate the difference in kinetic behavior between the two cheeses, $\mathrm{pH}$ and $\mathrm{a}_{\mathrm{w}}$ were measured. However, no difference

Table 1. Growth parameters (mean \pm standard error) of Staphylococcus aureus on mozzarella and cheddar cheese, calculated by the Baranyi model ${ }^{20)}$

\begin{tabular}{ccccccc}
\hline Cheese & $\begin{array}{c}\text { Storage } \\
\text { temperature }\left({ }^{\circ} \mathrm{C}\right)\end{array}$ & LPD $(\mathrm{h})$ & $\begin{array}{c}\mu_{\max } \\
\left(\log \text { CFU. } \mathrm{g}^{-1} \cdot \mathrm{h}^{-1}\right)\end{array}$ & $\begin{array}{c}N_{0} \\
(\log \text { CFU/g) }\end{array}$ & $\begin{array}{c}N_{\max } \\
(\log \text { CFU/g) }\end{array}$ & $R^{2}$ \\
\hline \multirow{3}{*}{ Mozzarella } & 15 & $48.00 \pm 1.63^{\mathrm{B}}$ & $0.02 \pm 0.00^{\mathrm{C}}$ & $3.5 \pm 0.0^{\mathrm{A}}$ & $8.4 \pm 0.1^{\mathrm{A}}$ & $0.964-0.996$ \\
& 25 & $5.69 \pm 3.85^{\mathrm{C}}$ & $0.18 \pm 0.05^{\mathrm{B}}$ & $3.0 \pm 0.2^{\mathrm{BC}}$ & $8.8 \pm 0.2^{\mathrm{A}}$ & $0.956-0.989$ \\
& 30 & $3.10 \pm 0.71^{\mathrm{C}}$ & $0.52 \pm 0.03^{\mathrm{A}}$ & $2.9 \pm 0.1^{\mathrm{C}}$ & $8.0 \pm 0.1^{\mathrm{A}}$ & $0.961-0.973$ \\
\hline \multirow{3}{*}{ Cheddar } & 15 & $130.01 \pm 16.59^{\mathrm{A}}$ & $0.01 \pm 0.02^{\mathrm{C}}$ & $3.1 \pm 0.1^{\mathrm{B}}$ & $4.9 \pm 0.2^{\mathrm{A}}$ & $0.785-0.859$ \\
& 25 & $21.98 \pm 2.07^{\mathrm{C}}$ & $0.11 \pm 0.02^{\mathrm{BC}}$ & $3.3 \pm 0.1^{\mathrm{AB}}$ & $7.5 \pm 0.1^{\mathrm{A}}$ & $0.946-0.958$ \\
& 30 & $0.08 \pm 0.08^{\mathrm{C}}$ & $0.16 \pm 0.01^{\mathrm{B}}$ & $2.4 \pm 0.1^{\mathrm{D}}$ & $8.3 \pm 0.8^{\mathrm{B}}$ & $0.977-0.981$ \\
\hline
\end{tabular}

$\mu_{\max }:$ maximum specific growth rate, LPD: lag phase duration, $N_{0}$ : lower asymptote, $N_{\max }$ : upper asymptote

A-D: different letters in a same column mean significantly different at $P<0.05$.

(A)

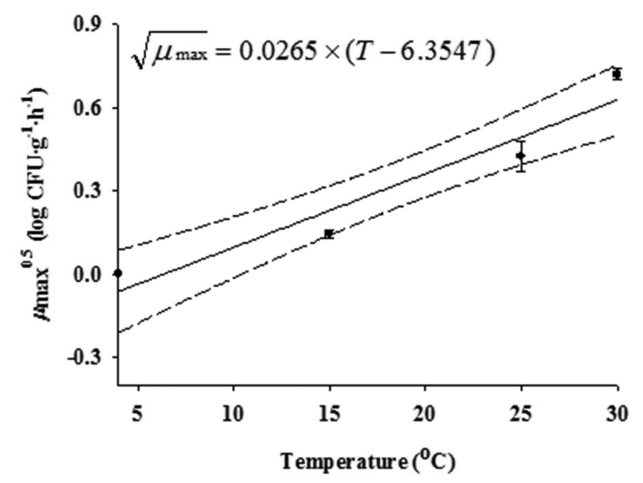

(B)

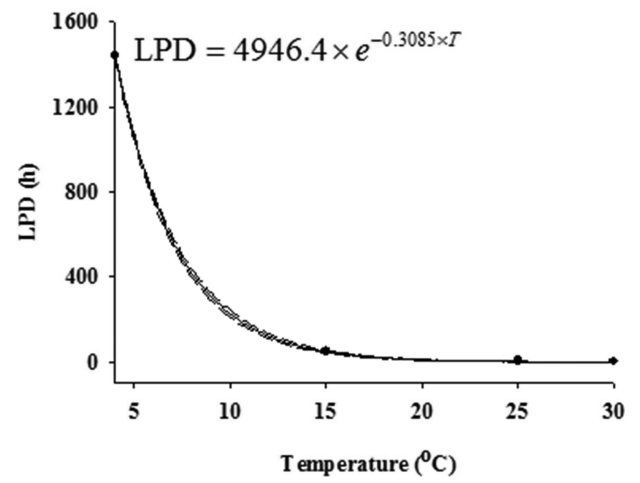

Fig. 1. Secondary model for $\mu_{\max }$ (A) and LPD (B) developed for mozzarella cheese. $\bullet:$ observed value; -: predicted value; -- : $95 \%$ confidence interval.

(A)

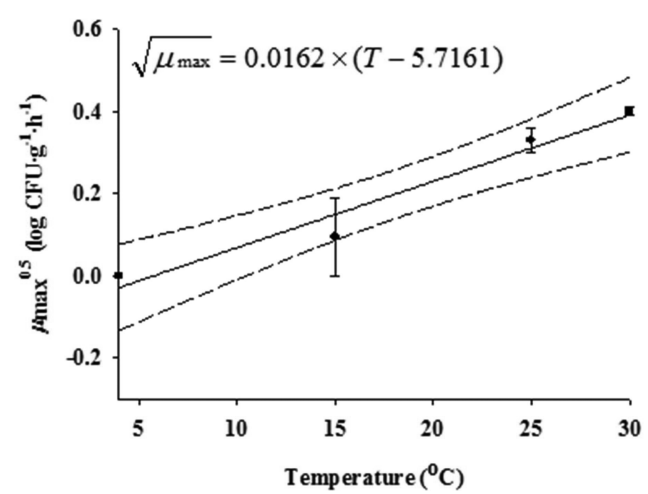

(B)

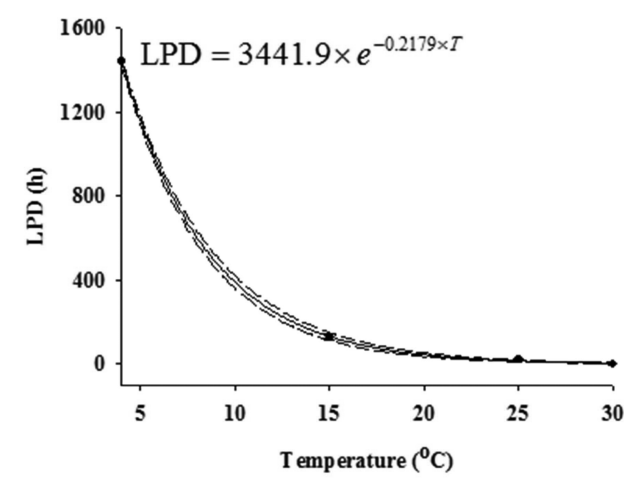

Fig. 2. Secondary model for $\mu_{\max }$ (A) and LPD (B) developed for cheddar. $\bullet:$ observed value; -: predicted value; -- : $95 \%$ confidence interval. 
was found in either $\mathrm{pH}$ (6.18-6.36) or $\mathrm{a}_{\mathrm{w}}$ values (0.9650.970 ) between the two cheeses. Therefore, further research is necessary to explain this phenomenon. Since $R^{2}$ values ranged from 0.785 to 0.996 , the developed primary model was considered an acceptable fit of the data (Table 1).

The effect of storage temperature on kinetic parameters was evaluated by fitting the square root model for kinetic parameters as a function of storage temperature. This showed that the square root of $\mu_{\max }$ and LPD increased as the storage temperature increased (Figs. 1 and 2). Similarly, a study by Lee et al. ${ }^{22)}$ also showed that the square root of $\mu_{\max }$ and square root of LPD for $S$. aureus are correlated with storage temperature. The $T_{\min }$ values for $S$. aureus were $6.35^{\circ} \mathrm{C}$ and $5.72^{\circ} \mathrm{C}$ for the mozzarella and cheddar slice cheeses, respectively (Figs. 1 and 2). In other studies, the $T_{\min }$ values for $S$. aureus were $5.82,5.2$, and $0.29^{\circ} \mathrm{C}$ in milk, carbonara sauce, and octopus sauce, respectively ${ }^{22}$. These results indicate that the theoretical minimum temperature for $S$. aureus varies depending on the bacterial strain and the food it is growing on. Furthermore, Dengremont and Membre ${ }^{23)}$ found a variation in the $T_{\min }\left(5.46-8.70^{\circ} \mathrm{C}\right)$ among five strains of $S$. aureus grown in culture medium. The secondary model describing the effect of the storage temperatures on kinetic parameters, provided a good fit for the observed values of $\mu_{\max }$ and LPD for the mozzarella and cheddar slice cheeses $\left(R^{2}=0.879-0.999\right)$ (data not shown).

To evaluate the performance of the developed models, an independent study was conducted at $23^{\circ} \mathrm{C}$ and $28^{\circ} \mathrm{C}$. The $S$. aureus cell counts observed at given storage temperatures $\left(23^{\circ} \mathrm{C}\right.$ and $\left.28^{\circ} \mathrm{C}\right)$ in the independent study, were compared with the cell counts predicted by the developed model. Bias factor and accuracy factors have been generally used, but Oscar ${ }^{24)}$ recently suggested that those factors have critical limitations. Hence, the RMSE was used to evaluate the model performance in our study. The RMSE values were 0.5344 and 0.3500 for the mozzarella and cheddar slice cheeses, respectively, the lower values of RMSE indicating that the developed model is more appropriate. This result indicates that the developed models are appropriate to predict $S$. aureus cell counts in the mozzarella and cheddar slice cheeses.

In conclusion, the results should be useful in predicting the growth pattern of $S$. aureus on processed cheeses. Moreover, this information could be useful in the microbiological exposure assessment for processed cheeses.

\section{Acknowledgement}

This work was supported by Research and Development in Veterinary Science, QIA (Animal, Plant and Fisheries Quarantine and Inspection Agency).

\section{요 약}

본 연구는 가공치즈에서 Staphylococcus aureus의 생장 을 예측하기 위한 수학적 모델을 개발하였다. 모짜렐라 슬 라이스 치즈와 체다 슬라이스 치즈에 S. aureus 혼합균액 (ATCC13565, ATCC14458, ATCC23235, ATCC27664, NC$\mathrm{CP} 10826) 0.1 \mathrm{ml}(\log \mathrm{CFU} / \mathrm{g})$ 을 접종한 후 $4^{\circ} \mathrm{C}(1440 \mathrm{~h})$, $15^{\circ} \mathrm{C}(288 \mathrm{~h}), 25^{\circ} \mathrm{C}(72 \mathrm{~h})$, and $30^{\circ} \mathrm{C}(48 \mathrm{~h})$ 에 저장하면서 총 세균 수와 S. aureus 세균 수를 tryptic soy agar와 mannitol salt agar를 이용해 각각 확인하였다. S. aureus의 세균 수 를 Baranyi model로 분석하여 생장률 $\left(\mu_{\max } ; \log \mathrm{CFU} \cdot \mathrm{g}^{-1} \cdot \mathrm{h}^{-1}\right)$, 유도기(LPD; h), 초기 세균수(log CFU/g), 최대 생장 세균 수 $(\log \mathrm{CFU} / \mathrm{g})$ 를 계산함으로써 1차 모델을 개발하였다. 또 한 저장온도와 $S$. aureus 의 $\mu_{\max }, \mathrm{LPD}$ 의 관계를 분석하기 위해 square root model과 exponential decay model을 이용 하였고 이를 통해 2 차모델을 개발하였으며 개발된 모델의 평균제곱근 편차(RMSE)를 계산하여 적합성을 검증하였다. $4^{\circ} \mathrm{C}$ 에서는 모든 가공치즈에서 황색포도상구균의 생장이 관찰되지 않았으나 $15^{\circ} \mathrm{C}, 25^{\circ} \mathrm{C}, 30^{\circ} \mathrm{C}$ 에서는 모짜렐라 슬 라이스와 체다 슬라이스 치즈에서 황색포도상구균이 생장 하였으며 $\left(R^{2}=0.785-0.996\right)$ 저장온도가 높아짐에 따라 생 장률은 증가한 반면 유도기는 감소하였다 $\left(R^{2}=0.879-0.999\right)$. 또한 개발된 모델의 RMSE 값은 $0.3500-0.5344$ 로 적합하 였다. 따라서 본 연구결과는 가공치즈에서 황색포도상구 균의 생장 예측에 유용하게 사용될 것이다.

\section{References}

1. Kim, H. J., Song, B. S., Kim, J. H., Choi, J., Lee, J. W., Jo, C., and Byun, M. W. Application of gamma irradiation for the microbiological safety of sliced cheddar cheese. J. Radiat. Ind. 1, 15-19 (2007).

2. Jo, C., Kim, H. J., Kim, D. H., Lee, W. K., Ham, J. S., and Byun, M. W. Radiation sensitivity of selected pathogens in ice cream. Food Control. 18, 859-865 (2007).

3. Tekinsen, K. K. and Özdemir, Z. Prevalence of foodborne pathogens in Turkish Van otlu (Herb) cheese. Food Control. 17, 707-711 (2006).

4. KFDA (Korea Food and Drug Administration) Status of food poisoning outbreaks in Korea. Available at: http://fm.kfda.go. kr. Accessed on March 23, 2013 (2013).

5. Dinges, M. M., Orwin, M., and Schlievert, P. M. Exotoxins of Staphylococcus aureus. Clin. Microbiol. Rev. 13, 16-34 (2000).

6. Glass, K. and Doyle, E. M. Safety of processed cheese: A review of the scientific literature. Available at: http://fri.wisc. edu/docs/pdf/ProcCheese.pdf. Accessed on December 5, 2012 (2005).

7. Tirado, C. and Schimdt, K. WHO surveillance program for control of foodborne infections and intoxication: preliminary results and trends across greater Europe. World Health Organization. J. Infect. 43, 80-84 (2001). 
8. Wieneke, A. A., Roberts, D., and Gilbert, R. J. Staphylococcal food poisoning in the United Kingdom 1969-90. Epidemiol. Infect. 110, 519-531 (1993).

9. Haran, K., Gooden, S. M., Boxrud, D., Jawahir, S., Bender, J. B., and Sreevatsan, S. Prevalence and characterization of Staphylococcus aureus, including methicillin-resistant Staphylococcus aureus, isolated from bulk tank milk from Minnesota dairy farms. J. Clin. Microbiol. 50, 688-695 (2011).

10. Zinke, C., Winter, M., Mohr, E., and Kromker, V. Occurrence of methicillin-resistant Staphylococcus aureus in cheese produced in German farm-dairies. Adv. Microbiol. 2, 629-633 (2011).

11. FDAP (Food and Drug Administration Philippines). Revised Guidelines for the Assessment of Microbiological Quality of Processed Foods. Available from: http://www.fda.gov.ph/ attachments/article/17218/FC2013-010.pdf. Accessed on November 13, 2012 (2013).

12. JETRO (Japan External Trade Organization). Specifications and standards for foods, food additives, etc. under the food sanitation act (Abstract) 2010. Available at: http://www.jetro. go.jp/en/reports/regulations/pdf/foodext2010e.pdf. Accessed on November 10, 2012 (2011).

13. MPI (Ministry for Primary Industries). Microbiological Reference Criteria for Food. Available at: http://www.foodsafety.govt.nz/elibrary/industry/microbiological_referenceguide_assess.pdf. Accessed on November 10, 2012 (1995).

14. QIA (Animal, Plant and Fisheries Quarantine and Inspection Agency) Standard for livestock product processing ingredients. pp. 14, 35-36 (2011).

15. Varga L. Microbiological quality of commercial dairy products In: Communicating Current Research and Educational Topics and Trends in Applied Microbiology. Méndez-Vilas A. (ed) Formatex Research Center, Badajoz. pp. 487-494 (2007).

16. Coroller, L., Guerrot, V., Huchet, V., Le Marc, Y., Mafart, P.,
Sohier, D., and Thuault, D. Modelling the influence of single acid and mixture on bacterial growth. Int. J. Food Microbiol. 100, 167-178 (2005).

17. Van Impe, J. F., Posche,t F., Geeraerd, A. H., and Vereecken, K. M. Towards a novel class of predictive microbial growth models. Int. J. Food Microbiol. 100, 97-105 (2005).

18. Lihono, M. A., Mendonca, A. F., Dickson, J. S., and Dixon, P. M. A predictive model to determine the effects of temperature, sodium pyrophosphate, and sodiuchloride on thermal inactivation of starved Listeria monocytogenes in pork slurry. J. Food Prot. 66, 1216-1221 (2003).

19. Xanthiakos, K., Simos, D., Angelidis, A. S., Nychas, G. J., and Koutsoumanis, K. Dynamic modeling of Listeria monocytogenes growth in pasteurized milk. J. Appl. Microbil. 100, 1289-1298 (2006).

20. Baranyi, J. and Roberts T. A. A dynamic approach to predicting bacterial growth in food. Int. J. Food Microbiol. 23, 277 294 (1994).

21. McClure, P. J., Beaumont, A. L., Sutherland, J. P., and Roberts, T. A. Predictive modeling of growth of Listeria monocytogenes: the effects on growth of $\mathrm{NaCl}, \mathrm{pH}$, storage temperature and sodium nitrate. Int. J. Food Microbiol. 34, 221-232 (1997).

22. Lee, J., Skandamis, P., Park, A., Yoon, H., Hwang, I. G., Lee, S. H., Cho, J. I., Yoon, Y. Development of mathematical models to predict Staphylococcus aureus growth in sauces under constant and dynamic temperatures. Food Sci. Technol. Res. 19, 331-335 (2013).

23. Dengremont, E. and Membre, J. M. Statistical approach for comparison of the growth rates of five strains of Staphylococcus aureus. Appl. Environ. Microbiol. 61, 4389-4395 (1995).

24. Oscar, T. Validation of lag time and growth rate models for Salmonella Typhimurium: acceptable prediction zone method. J. Food Sci. 70, M129-M137 (2005). 